\title{
Ampulla of Vater Cancer pTO TNM Finding V8
}

National Cancer Institute

\section{Source}

National Cancer Institute. Ampulla of Vater Cancer pT O TNM Finding v8. NCI Thesaurus.

Code C134847.

Ampulla of Vater cancer with no evidence of primary tumor. (from AJCC 8th Ed.) 